\title{
Usporedba dviju fizioterapijskih metoda kod nespecifične boli u vratu
}

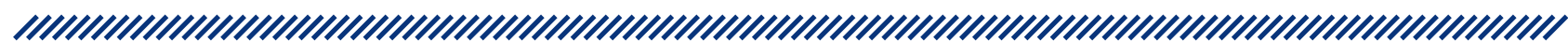

1 Tomislav Rumbak

2 Olivera Petrak

1 Specijalna bolnica za medicinsku rehabilitaciju Krapinske toplice

2 Katedra za zdravstvenu psihologiju, Zdravstveno veleučilište Zagreb

\section{Sažetak}

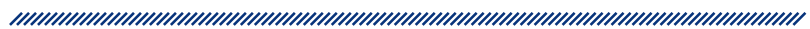

Bol u vratu jedna je od najčešćih bolnih senzacija uzrokovana dugotrajnim zadržavanjem glave $u$ jednom položaju, dugotrajnom stereotipnom aktivnošću ruku ispred tijela, sve manjom zastupljenošću dinamičkih aktivnosti te stresom. Bol je popraćena smanjenom pokretljivošću vrata te poteškoćama s ravnotežom, poglavito u kroničnom stanju. lako postoje brojne metode kojima se tretira nespecifična bol u vratu, nisu popraćene zadovoljavajućim brojem istraživanja o djelotvornosti.

Cilj je rada utvrditi djelotvornost dvaju različitih fizioterapijskih pristupa u smanjenju boli, povećanju sagitalnog, frontalnog i transverzalnog indeksa gibljivosti te poboljšanju ravnoteže osoba s nespecifičnom boli u vratu.

Istraživanje je provedeno u Specijalnoj bolnici za medicinsku rehabilitaciju Krapinske Toplice, a sudjelovalo je 30 pacijenata, pri čemu su polovicu tretirali fizioterapeuti kroz metode manipulacije mekog tkiva, trakciju i mobilizaciju glave (relaksacijska skupina), dok je druga skupina od petnaest sudionika educirana za izvođenje statičkih vježbi snage i vježbi disanja u svrhu relaksacije (izometrička skupina). Promatrane varijable, opseg pokreta, bol i balans, mjerene su prije i nakon terapije u trajanju od 15 dana. Uzorak je sastavljen od $80 \%$ žena i $20 \%$ muškaraca, prosječna je starost u izometričkoj skupini 55,6 godina, a u relaksacijskoj skupini 52,4 godina. Nema značajne razlike među skupinama po dobi, spolu, kao ni po promatranim kriterijima.

Prije terapije prisutna je jaka bol, pokretljivost vrata je ograničena, a održavanje ravnoteže na jednoj nozi kratkotrajno, pri čemu ne postoji značajna razlika među skupinama. Rezultati nakon terapije pokazuju pozitivne pomake, uz velik glavni efekt: obje metode znatno djeluju na smanjenje boli, povećanje gibljivosti u sve tri promatrane ravnine te rezultatima na testu ravnoteže na klupici i testu „ustani i kreni”. Među skupinama nema znatne interakcije ni za jedan promatrani kriterij.

Značajne razlike u djelotvornosti dviju terapija dobivene su za frontalnu gibljivost te za ravnotežu na desnoj nozi, gdje izometrička skupina pokazuje znatno veći napredak. Obje terapijske metode ublažile su tegobe i poboljšale stanje pacijenata s nespecifičnom boli u vratu, a postoje sporadični pokazatelji o većoj djelotvornosti statičkih vježbi snage i vježbi disanja.

Ključne riječi: nespecifična bol u vratu, pokretljivost vrata, manipulacija i mobilizacija vrata, izometričke vježbe za vrat

Datum primitka: 29.05.2015.

Datum prihvaćanja: 01.05.2017.

DOI: $10.24141 / 3 / 1 / 9$

Adresa za dopisivanje:

Olivera Petrak

Katedra za zdravstvenu psihologiju,

Zdravstveno veleučilište, Ksaver 209, 10000 Zagreb

E-pošta: olivera.petrak@zvu.hr

Tel.: +385914595927 


\section{Uvod}

Bol u vratu jedna je od najčešćih bolnih senzacija uzrokovana suvremenim načinom života. ${ }^{1}$ Razlog je tome dugotrajno zadržavanje glave u jednom položaju, dugotrajna stereotipna aktivnost ruku ispred tijela (vožnja auta, rad na nekom stroju), ${ }^{2}$ sve manja zastupljenost dinamičkih aktivnosti ${ }^{3}$ i psihosocijalni stres. ${ }^{4}$ Promjena u funkcioniranju vrata zbog boli bez vidljivih strukturalnih promjena naziva se nespecifičnom boli u vratu. Ako su simptomi (trnci, žarenje, gubitak snage, kontrole nad mišićima, bol) lokalizirani u vratu, govorimo o cervikalnom sindromu, uz što je vezan pojam cervikogene boli. ${ }^{5}$

Do sada provedena istraživanja pokazuju da je prosječna dob pojave simptoma 42,9 godina s omjerom $4: 1$ za žensku populaciju. U cjelokupnoj populaciji osoba s glavoboljom, 15 do $20 \%$ glavobolja nastaje uslijed promjena u vratu, ${ }^{5}$ dok će $78 \%$ osoba koje rade u uredu imati nespecifičnu bol u vratu. ${ }^{1}$

Vrat je specifičan jer na njemu balansira glava, prijelaz je pokretnog u nepokretni dio kralježnice, površinski mišići imaju ulogu pokretanja i stabilizacije glave, vrata i lopatice. ${ }^{6}$ Bol u mišićima znak je upalnog procesa i takav mišić ne može kvalitetno obavljati svoju zadaću. Promjene u mišićima (zamorenost, skraćenost, gubitak snage, bol) uzrokuju promjene u pokretanju (manje proprioceptivnih informacija) i stabilnosti zgloba, što dovodi do jačeg opterećenja mišića s nastankom većih promjena, što dalje u krug stvara bolne tegobe. ${ }^{2}$ Javlja se problem zakočenosti i težine u vratu, vrtoglavice te nesigurnosti u kretanju jer osoba slabije provjerava okolinu. Prilikom nagloga voljnog pokreta ili gubitka ravnoteže javljaju se bol i strah od pada, što povećava napetost u mišićima, a to dodatno smanjuje pokretljivost. Osoba traži antalgičan položaj vrata i glave u kojem će vratni mišići biti manje napeti. Ako bolno stanje potraje, poteškoće u održavanju uspravnog stava tijela i disanja mogu postati trajni problem pa nespecifična bol u vratu često prelazi u kroničnu bol. To se očituje u poremećenom redoslijedu aktivnosti mišića zbog promjene u mapama senzomotoričkog korteksa. ${ }^{7,8,9}$ Najčešći je problem slabost i nekoordiniranost u dubokim mišićima vrata te skraćenost i zamorenost površinskih mišića. ${ }^{10}$ Nastajanje navedenih promjena može trajati godinama. Duboki mišići vrata kasne i postaju manje aktivni, površinski mišići postaju aktivniji u funkcionalnim aktivnostima, što uzrokuje njihovu atrofiju i infiltraciju masnim stanicama. ${ }^{11}$
Način na koji nastaje zamor u mišićnim vlaknima i infiltracija masnih stanica objašnjava Hagg $^{12}$ u hipotezi Cinderella (hipoteza Pepeljuga). Funkcionalne jedinice mišića regrutiraju se hijerarhijski prema Hennemanovu principu veličine, tj. prve se aktiviraju najmanje motorne jedinice $s$ najmanjim pragom podražljivosti. Taj princip je naveo Hagga na teoriju da pojedina mišićna vlakna više rade u specifičnim situacijama. Zbog prolongirane kontrakcije pojedinih mišićnih vlakana u statičnoj ili dinamičnoj kontrakciji dolazi do energetskog nerazmjera u potrošnji unutar mišića. Posljedica je porast lokalnog intermuskularnog tlaka oko tih vlakana, što dovodi do smanjenog dotoka krvi mišićnim vlaknima kojima je najpotrebnije. Veći rad zahtijeva više hranjivih tvari, masnih stanica, koje se nakupljaju u mišiću, ali se ne troše zbog prevelike zamorenosti mišića. Kadi i suradnici ${ }^{13}$ našli su vlakna unutar mišića koja više rade u statičkim i dinamičkim kontrakcijama, a biopsija kod osoba s nespecifičnom boli u vratu ukazuje na različite strukturalne promjene stanica i promjene povezane s mitohondrijima, što je potvrdilo hipotezu Cinderella. Zbog veće aktivnosti površinskih mišića moguća je i razlika u tonusu unutar istog mišića ili mišićnih skupina.

Asimetrija vrata zbog lošeg držanja negativno utječe na usmjerenje pogleda, praćenje okoline i ravnotežne reakcije u stajanju ili hodanju i primjećuje se $26 \%$ veće antero-posteriorno njihanje. ${ }^{14}$ Kod osoba koje imaju slabiji vid vratni mišići rade više jer osoba protrakcijom i retrakcijom glave pokušava fokusirati sliku predmeta na žutoj pjegi, što kod stereotipnih aktivnosti izaziva brže zamaranje mišića nego kod osoba s normalnim vidom. ${ }^{8}$ Osobe s nespecifičnom boli u vratu imaju slabije rezultate $u$ testu stajanja na jednoj nozi u odnosu na osobe bez boli. ${ }^{6}$ lako 57 do $61 \%$ sudionika bez boli u vratu ili križima ne može stajati 30 sekundi na jednoj nozi, svejedno autori navode da nespecifična bol u vratu ima veći negativni utjecaj na ravnotežu nego starost. Normalna pokretljivost vrata za fleksiju iznosi 45 do $50^{\circ}$, ekstenziju 75 do $80^{\circ}$, laterofleksiju jednostrano $45^{\circ}$ i rotaciju jednostrano 60 do $80^{\circ} .{ }^{15}$ Kompleksna građa vrata izazov je za točno određivanje opsega pokreta u pojedinom zglobu. Pokretljivost kralježnice utvrđena je preko rendgenskih slika ili postmortalnim istraživanjima, goniometri i razni optički ili električni uređaji za neinvazivnu procjenu cervikalne gibljivosti nisu dovoljno točni, ${ }^{16}$ a novije metode, kao npr. posturografija, skupe su i nedostupne većini istraživača. Osim toga, još uvijek nije do kraja poznato na koji način zglobovi vrata u međudjelovanju sudjeluju u složenoj kretnji. ${ }^{17}$ Stoga je bol u vratu kompleksan problem koji treba tako i tretirati. ${ }^{4}$ 
Usprkos velikom broju metoda kojima se može tretirati problem slabosti, skraćenosti, zamorenosti i nekoordiniranosti mišića vrata, podatak o efikasnosti primijenjenih metoda izostaje. ${ }^{18}$ Još uvijek nije poznato koja kombinacija metoda daje najbolje rezultate, ${ }^{19}$ a dodatni problem predstavlja pitanje njihove ekonomske isplativosti s obzirom na uloženo vrijeme. ${ }^{20}$ Akutnu bol brže smanjuje mobilizacija kralježnice nego manipulacija tkiva ili fizioterapija. ${ }^{21}$ Trening snage u trajanju od 20 tjedana, jedan sat tjedno, znatno smanjuje bol kod žena u uredu ${ }^{19}$ ili muškaraca u industriji. ${ }^{3}$ Učestalo se bol u mišiću liječi vježbama snage okolnih, nebolnih mišića, a dokazano je i da jaki trening snage na bolnom mišiću u vratu dovodi do smanjenja boli. ${ }^{22}$ Isti tretman ne djeluje na žene, odnosno navedena je mogućnost nastanka komplikacija kod sudionica. ${ }^{4}$ Pokazuje se da su tretmani kronične boli mobilizacija kralježnice i manipulacija tkiva, i to po intenzitetu i po brzini djelovanja, djelotvorniji u odnosu na fizikalnu terapiju i vježbe za cijelo tijelo. ${ }^{21,23}$ Manipulacija tkiva u usporedbi s mobilizacijom kralježnice ima bolji učinak. ${ }^{20,24}$ Izometrički trening snage i trening izdržljivosti jednako smanjuju kroničnu bol na razinu slabe boli u vremenu od 12 mjeseci vježbanjem tri puta tjedno u usporedbi s vježbama disanja i istezanja. ${ }^{18}$ Kombinacija toplog obloga, ultrazvuka i kineziterapije preporučuje se za smanjenje kronične boli, ali ne i primjena intermitentne trakcije. ${ }^{25}$ Najbolje su metode za smanjenje kronične boli u vratu cervikalna manipulacija, TENS i butolinum toxin. ${ }^{5}$ Postoje proturječni dokazi o dugoročnosti učinka tretmana: neki navode da je potrebna godina dana da se 33 do $65 \%$ osoba izliječi od kronične boli, a česta su iskustva da se bol vraća. ${ }^{22}$ Problem boli i smanjene pokretljivosti rješava se vježbama, manualnim tehnikama, vježbama disanja ili ergonomskim savjetima, što daje pozitivne rezultate, ali kratkog trajanja i problem se vraća. ${ }^{1}$

$\mathrm{U}$ radovima starijeg datuma istražuje se djelovanje terapijskih procedura na smanjenje boli, ${ }^{5,20,21,23}$ dok se u novijim istraživanjima provodi edukacija za vježbe s osobama s povećanim rizikom od nespecifične boli u vratu, uz praćenje. Najnovija istraživanja uz primjenu modernih uređaja (posturografija, konzola Nintendo Wii) pokazuju da tretiranje poremećaja ravnoteže može djelovati na smanjenje boli i povećanje pokretljivosti vrata. ${ }^{26-28}$

U Krapinskim toplicama primjenjuju se dvije terapijske metode nastale kombinacijom nekoliko tehnika u tretmanu nespecifične boli u vratu. Jednu metodu provodi fizioterapeut kroz manipulaciju mišića vrata, trakciju i mobilizaciju vrata. Druga metoda temelji se na edukaciji za izvođenje statičkih vježbi snage i vježbi disanja u svrhu relaksacije. Bilježi se broj terapija, opseg pokreta i bol prije i nakon tretmana, ali nema podatka koja je terapijska metoda primijenjena, pa je usporedba njihove djelotvornosti onemogućena, a također je nepoznato djelovanje na poboljšanje ravnoteže.

Povećanje učestalosti spomenutih tegoba u vratu, a koje nije adekvatno popraćeno istraživanjima o njihovu tretmanu, predstavljalo je poticaj za naše istraživanje. Cilj je našeg rada unaprijediti spoznaje o nespecifičnoj boli u vratu, pri čemu želimo utvrditi djelotvornost dvaju različitih fizioterapijskih pristupa u smanjenju boli, povećanju sagitalnog, frontalnog i transverzalnog indeksa gibljivosti i poboljšanju ravnoteže osoba s nespecifičnom boli u vratu. Na temelju dosadašnjih istraživanja očekujemo poboljšanje statusa pacijenata u obje skupine, a moguće je, u skladu s hipotezom Cinderella, da će eventualna razlika u njihovoj učinkovitosti biti u korist izometričke skupine.

\section{Metode}

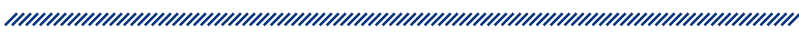

Istraživanje je provedeno tijekom 2013. godine u Specijalnoj bolnici za medicinsku rehabilitaciju Krapinske toplice.

\subsection{Sudionici}

$\mathrm{U}$ istraživanju je sudjelovalo 30 osoba s bolovima u vratu koje nisu imale trzajnu povredu vrata, reumatske promjene kralježnice, operaciju u području vrata ili zračenje, a koje su upućene u Krapinske toplice na terapiju. Svi su sudionici ambulantni pacijenti. Zajednički kriterij sudionika bio je bavljenje poslom koji iziskuje aktivnost ruku i zadržavanje tijela duže vrijeme u radu, o čemu je podatak dobiven iz anamneze. Uzorak je prigodni, sastavljen od $80 \%$ žena i $20 \%$ muškaraca. Naočale upotrebljava $87 \%$ sudionika, lijekove protiv bolova uzima $57 \%$, a $27 \%$ sudionika uzima lijekove za smirenje. Sudionici su podijeljeni u dvije skupine: izometričku i relaksacijsku (objašnjeno u Postupku). Prosječna je starost sudionika u izometričkoj skupini 55,6 godina, a u relaksacijskoj skupini 52,4 godina. Skupine se međusobno značajno ne razlikuju po dobi $(t=1,347 ; d f=28 ; p=0,189)$, po tome nose li naočale ili ne (Fisherov egzaktni test; $p=0,0996$ ), uzimaju li lijekove protiv bolova $(p=1,000)$ odnosno antidepresive $(p=1,000)$, kao ni po spolu $(p=0,1686)$. 


\subsection{Postupak}

Nakon informativnog razgovora, u kojem je objašnjeno o kakvom je istraživanju riječ, pristupilo se početnom testiranju boli, indeksa gibljivosti u vratu i ravnoteže. U suradnji s liječnikom, grupe su se popunjavale tako da budu uravnotežene po važnim obilježjima (dob, spol, intenzitet boli). Obje grupe imale su djelomično istovrstan tretman koji je uključivao grupne vježbe u bazenu i dvorani, podvodnu masažu, TENS i IFS. Različito im je bilo provode li s njima fizioterapeuti izometričke ili relaksacijske vježbe, a odvijale su se u istoj dvorani. Pacijenti nisu bili upućeni u dijagnoze drugih osoba u dvorani, odnosno nisu svi bili u istom periodu u terapiji. Redoslijed aktivnosti u tretmanu nije bio ujednačen, pa je tako određeni broj pacijenata u objema grupama prvo obavljao ovaj zajednički dio tretmana, a potom diferencijalni tretman, dok su drugi radili obratno, a poneki su varirali redoslijed tretmana po vlastitom nahođenju. Tretman je trajao petnaest radnih dana i osoba ga je morala provesti unutar mjesec dana. Na kraju tretmana napravljeno je završno testiranje. Četiri mjeseca bilo je potrebno da se prikupi i testira trideset sudionika. Izometrička skupina, sastavljena od deset žena i pet muškaraca, primala je tretman fizioterapeuta kroz metode manipulacije mekog tkiva, trakciju i mobilizaciju glave. Relaksacijska skupina sastoji se od četrnaest žena i jednog muškarca, a educirana je za izvođenje statičkih vježbi snage i vježbi disanja u svrhu relaksacije.

Tretman u relaksacijskoj skupini sastoji se od sljedećih postupaka. Osoba sjedi naslonjena na naslon stolca s rukama na nogama. Fizioterapeut započinje terapiju laganom masažom mišića ramenog obruča i paravertebralne muskulature. Nakon masaže radi se trakcija glave šesnaest puta. Slijedi manipulacija mišića ramenog obruča i paravertebralne muskulature u tri dijela, između kojih se radi trakcija i mobilizacija glave u sagitalnoj, frontalnoj i transverzalnoj ravnini. Prvo se izvodi trakcija, napravi se pokret, glava se vrati u srednji položaj i popusti trakcija. U suprotnom se smjeru sve odvija po istom redoslijedu i ponavlja se šesnaest puta, a nakon toga se mijenja ravnina u kojoj se izvodi mobilizacija. Tretman završava laganom masažom i pokretima ruku u kojima osoba širi ruke pa se grli, a terapeut na kraju pokreta malo poveća amplitudu izvedenog pokreta. Cijeli tretman traje dvanaest minuta, a odvija se jednom dnevno kroz period od petnaest radnih dana.

U izometričkoj skupini osoba leži u supiniranom položaju s glavom naslonjenom na jastuk. Dobiva uputu da glavom gurne krevet i da je cilj vježbi osjetiti napetost u miši- ćima koji su aktivni. Dok traje guranje, osoba izdiše. Kad je izdisaj gotov, prekida se guranje. U fazi odmora pažnja je usmjerena na disanje i na opuštanje istih onih mišića u kojima se osjetila napetost prilikom aktivnosti. Nakon svladavanja pokazane vježbe osoba može raditi naizmjenično aktivnost u kojoj kombinira pokrete $u$ istoj ravnini, a otpor pokretu daje rukama. $U$ početku se radi pet ponavljanja, odmor i pet ponavljanja. Kad osoba uskladi disanje i aktivnost, a nema umora ili crvenila u licu, može napraviti deset ponavljanja, odmor i deset ponavljanja. Tretman traje deset minuta, a odvija se jednom dnevno kroz period od petnaest radnih dana. Nijedna grupa tijekom tretmana nije dobila upute da nastavi vježbati kod kuće, već tek nakon završenog tretmana.

\subsection{Varijable}

Varijable su koje se mjere opseg pokreta, bol i balans. Opseg pokreta u vratu mjeren je centimetarskom trakom. Sudionik sjedi na stolici s naslonom, a ruke su opuštene uz strane stolca. Korištene su sljedeće antropometrijske točke: vertebra prominens $\mathrm{C} 7$ i protuberantia occipitalis externa za reklinacijski i inklinacijski indeks, vrh mastoidnog nastavka temporalne kosti i vrh akromiona za laterofleksiju te vrh brade i vrh akromiona za rotaciju. Izmjerena je udaljenost u nultom položaju pa udaljenost nakon izvedenog pokreta i dobivena je razlika u centimetrima koja je zbrojena s razlikom pokreta u istoj ravnini, npr. zbrojeni su inklinacijski i reklinacijski indeks te je dobiven indeks sagitalne gibljivosti koji je normalan ako je veći od 10 centimetara.

Bol se procjenjuje na vizualno-analognoj skali boli (VAS) gdje osoba na skali od 0 (nema boli) do 10 (najjača bol) odabire broj koji najbolje odgovara njezinoj boli.

Balans se procjenjuje testom „timed up and go" i testom stajanja jednom nogom na klupici. ${ }^{29}$ Test ravnoteže na klupici izveden je na lijevoj i desnoj nozi. Na desnoj nozi ispitanik stoji poprečno na klupici, a na lijevoj uzdužno. Netestirana noga podignuta je do devedeset stupnjeva u fleksiji i držana je za koljeno rukom s iste strane, a suprotna služi za održavanje ravnoteže. Vrijeme se zaustavlja ako ispitanik traži prekid, odvoji ruku od koljena, izgubi ravnotežu ili izdrži dvije minute. Klupica visine deset centimetara mijenja visinu na kojoj sudionik percipira okolinu, a promjenom smjera izbjegava se da ispitanik u drugom stajanju traži iste točke za orijentaciju u prostoru, što uz stajanje na jednoj nozi iziskuje adekvatne ravnotežne reakcije da se taj položaj zadrži. Test „ustani i kreni" izveden je na udaljenosti od tri metra. Ispitanik iz naslonjenoga sjedećeg položaja mora ustati, proći tri 
metra, okrenuti se, vratiti do stolca i sjesti. Test traži naglu promjenu položaja prilikom ustajanja i okreta, a trajanje normalne izvedbe mora biti manje od 10 sekundi. ${ }^{29}$

\section{Rezultati}

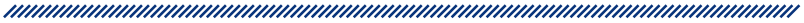

Kako bismo dobili odgovor na postavljene istraživačke probleme, provedena je analiza varijance za ponovljena mjerenja. Provjera preduvjeta za njezino korištenje pokazala se zadovoljavajućom. Usporedba rezultata ttestom u prvom mjerenju primjenjuje se u svrhu provjere uravnoteženosti skupina po relevantnim obilježjima. Grupe se inicijalno međusobno značajno ne razlikuju ni u jednoj zavisnoj varijabli. Deskriptivna statistika promatranih varijabli za obje skupine nalazi se u tablici 1 .

Nakon terapije bol se u izometričkoj skupini smanjila kod trinaest, a u relaksacijskoj skupini kod četrnaest pacije- nata. Analiza varijance pokazala je statistički značajno smanjenje boli u obje skupine, pri čemu je glavni efekt terapije, izražen kao parcijalno kvadrirano eta izrazito velik $(0,76)$. Među grupama nema znatne interakcije, niti se one međusobno značajno razlikuju (tablica 2.).

Osim jačine boli, zanimalo nas je djelovanje terapijskih metoda na pokretljivost vrata u različitim ravninama. Za sve promatrane indekse gibljivosti (sagitalna, frontalna i transverzalna) utvrđen je znatan, velik glavni efekt djelovanja terapije ${ }^{30}(0,32$ do 0,51$)$, a interakcije među grupama nisu znatne. Nema značajne razlike među grupama u sagitalnoj gibljivosti: poboljšanje u izometričkoj skupini iznosi $0,67 \mathrm{~cm}$, a u relaksacijskoj skupini $0,63 \mathrm{~cm}$. Promatrane skupine značajno se razlikuju po indeksu frontalne gibljivosti. Frontalna gibljivost $u$ izometričkoj skupini poslije terapije povećana je u prosjeku za $2,6 \mathrm{~cm}$, dok u relaksacijskoj skupini poboljšanje iznosi $2,5 \mathrm{~cm}$. Transverzalna gibljivost nakon terapije znatno je povećana i u izometričkoj i u relaksacijskoj skupini. lako je indeks u izometričkoj skupini povećan za $2 \mathrm{~cm}$, a u relaksacijskoj za $3,6 \mathrm{~cm}$, među grupama nema statistički značajne razlike.

Tabela 1. Deskriptivna statistika za jačinu boli, indekse sagitalne, frontalne i transverzalne gibljivosti, te test ravnoteže na klupici i "ustani kreni" test između mjerenja prije i poslije terapije za izometričku (N=15) i relaks skupinu ( $\mathbf{N}=15)$.

\begin{tabular}{|c|c|c|c|c|c|}
\hline \multirow[b]{2}{*}{ Varijabla } & \multirow{2}{*}{$\frac{\text { Skupina }}{\text { Mjerenje }}$} & \multicolumn{2}{|c|}{ Izometrička } & \multicolumn{2}{|c|}{ Relaks } \\
\hline & & M & $\mathrm{SD}$ & M & SD \\
\hline \multirow{2}{*}{ Jačina boli } & 1. & 6,67 & 1,54 & 6,8 & 1,45 \\
\hline & 2. & 4,2 & 1,74 & 3,8 & 1,78 \\
\hline \multirow{2}{*}{ Sagitalna gibljivost } & 1. & 8,23 & 1,15 & 8,33 & 1,55 \\
\hline & 2. & 8,9 & 1.37 & 8,96 & 1,54 \\
\hline \multirow{2}{*}{ Frontalna gibljivost } & 1. & 8,07 & 2,52 & 10,2 & 3,08 \\
\hline & 2. & 10,67 & 2,31 & 12,7 & 3,8 \\
\hline \multirow{2}{*}{ Transverzalna gibljivost } & 1. & 15,8 & 3,14 & 17,47 & 4,77 \\
\hline & 2. & 17,8 & 3,28 & 21,07 & 4,68 \\
\hline \multirow{2}{*}{$\begin{array}{l}\text { Ravnoteža } \\
\text { Desna noga }\end{array}$} & 1. & 31,8 & 18,3 & 23 & 7,9 \\
\hline & 2. & 57,27 & 29 & 36,8 & 13,8 \\
\hline \multirow{2}{*}{$\begin{array}{l}\text { Ravnoteža } \\
\text { Lijeva noga }\end{array}$} & 1. & 32,4 & 24,2 & 23,2 & 10,2 \\
\hline & 2. & 61,46 & 26,9 & 46 & 20 \\
\hline \multirow{2}{*}{ Ustani kreni test } & 1. & 8,4 & 0,98 & 8,07 & 1,16 \\
\hline & 2. & 6,47 & 0,83 & 6,47 & 0,83 \\
\hline
\end{tabular}


Tabela 2. Analiza varijance ponovljenih mjerenja (prije i poslije terapije) za jačinu boli, sagitalnu, frontalnu i transverzalnu gibljivost, test ravnoteže na klupici i "ustani kreni" test za izometričku ( $\mathbf{N = 1 5 )}$ i relaks skupinu $(\mathbf{N}=15)$.

\begin{tabular}{|c|c|c|c|c|}
\hline & & $\mathrm{F}$ & $\mathrm{P}$ & Parc. $\eta^{2}$ \\
\hline \multirow{3}{*}{ Jačina boli } & Glavni efekt & 88,483 & 0,000 & 0,760 \\
\hline & Interakcija & 1,040 & 0,316 & 0,316 \\
\hline & Efekt među grupama & 0,037 & 0,849 & 0,001 \\
\hline \multirow{3}{*}{ Sagitalna gibljivost } & Glavni efekt & 13,112 & 0,001 & 0,319 \\
\hline & Interakcija & 0,009 & 0,927 & 0,000 \\
\hline & Efekt među grupama & 0,032 & 0,858 & 0,001 \\
\hline \multirow{3}{*}{ Frontalna gibljivost } & Glavni efekt & 27,642 & 0,000 & 0,497 \\
\hline & Interakcija & 0,011 & 0,919 & 0,000 \\
\hline & Efekt među grupama & 4,549 & 0,042 & 0,140 \\
\hline \multirow{3}{*}{ Transverzalna gibljivost } & Glavni efekt & 28,872 & 0,000 & 0,508 \\
\hline & Interakcija & 2,357 & 0,136 & 0,078 \\
\hline & Efekt među grupama & 3,193 & 0,085 & 0,102 \\
\hline \multirow{3}{*}{$\begin{array}{l}\text { Ravnoteža } \\
\text { Desna noga }\end{array}$} & Glavni efekt & 38,415 & 0,000 & 0,578 \\
\hline & Interakcija & 3,341 & 0,078 & 0,107 \\
\hline & Efekt među grupama & 5,666 & 0,024 & 0,168 \\
\hline \multirow{3}{*}{$\begin{array}{l}\text { Ravnoteža } \\
\text { Lijeva noga }\end{array}$} & Glavni efekt & 66,562 & 0,000 & 0,704 \\
\hline & Interakcija & 0,972 & 0,333 & 0,034 \\
\hline & Efekt među grupama & 3,022 & 0,093 & 0,097 \\
\hline \multirow{3}{*}{ Ustani kreni test } & Glavni efekt & 127,682 & 0,000 & 0,820 \\
\hline & Interakcija & 1,136 & 0,296 & 0,039 \\
\hline & Efekt među grupama & 0,280 & 0,601 & 0,010 \\
\hline
\end{tabular}

Jedan od istraživačkih problema bio je i djelovanje dvaju različitih tretmana nespecifične boli u vratu na ravnotežne reakcije.

Provedene terapije pokazuju vrlo visoke učinke u testu ravnoteže na klupici i za desnu i za lijevu nogu, kao i za rezultat na testu „ustani i kreni” $(0,58$ do 0,82). Fisherovim egzaktnim testom za svaku je skupinu provjereno postoji li značajna razlika u broju sudionika koji prije i nakon provedene terapije mogu stajati na desnoj ili lijevoj nozi 30 ili 60 sekundi. $U$ obje skupine uslijed terapije znatno se povećava broj osoba koje mogu stajati na lijevoj nozi 30 sekundi (izometrička $p=0,02$; relaksacijska $p=0,03$ ), a nakon terapije u izometričkoj je skupini znat- no veći broj onih koji mogu stajati 60 sekundi na desnoj nozi $(p=0,014)$.

Skupine se značajno razlikuju u ravnoteži desne noge, gdje napredak iznosi 25,47 sekundi u izometričkoj skupini, u odnosu na relaksacijsku skupinu, gdje je napredak 13,87 sekundi. Stajanje na lijevoj nozi u izometričkoj skupini u prosjeku je produljeno za 28,8 sekundi, a u relaksacijskoj skupini za 22,67 sekundi, ali među grupama nema znatne razlike. Poboljšanje u brzini izvođenja testa „ustani i kreni” nakon tretmana u izometričkoj skupini iznosi 1,93 sekunde, a u relaksacijskoj skupini 1,6 sekundi. Navedena razlika nije statistički značajna. Interakcija se nigdje nije pokazala značajnom. 


\section{Diskusija}

U ovom istraživanju zanimalo nas je kako dvije različite terapijske metode djeluju na jačinu boli, indeks gibljivosti u vratu i ravnotežne reakcije kod osoba s nespecifičnom boli u vratu.

Prije terapije prosječna bol sudionika bila je jaka (7 bodova), a pokretljivost vrata mala. U prosjeku osoba može pokrenuti glavu $4 \mathrm{~cm}$ prema dolje ili gore, što nije dovoljno da bez poteškoća skine odjeću preko glave ili nagne glavu unazad. Prosječna laterofleksija od $4,5 \mathrm{~cm}$ ne omogućava izvođenje radnji s naginjanjem glave u stranu. Prosječna rotacija u jednu stranu iznosi $8 \mathrm{~cm}$, što ne zadovoljava brzu provjeru lijevo-desno u prometu. Sudionici se žale na smetnje zakočenosti, težine u vratu, vrtoglavice te nesigurnost u okretanju, hodu ili radu. Navode sijevanje boli u glavu, trnu im ruke, žale se na hladne ruke i nemaju spretnost. Bol se uvijek javlja u mišićima stražnje strane vrata, može biti stalno prisutna ili periodična, često ih bol budi noću, a pola su sata nakon buđenja bol, zakočenost i težina u vratu najintenzivniji. Stoga ne iznenađuje podatak da lijekove protiv bolova uzima 57 \% sudionika, ali navode da nastavljaju s aktivnostima dok bol ne postane nepodnošljiva. $27 \%$ sudionika uzima antidepresive za opuštanje prije spavanja kako bi se mogli naspavati. Pacijenti inače, pa tako i naši sudionici, važnijim kriterijem uspješnosti terapije smatraju smanjenje boli, dok im je povećanje pokretljivosti manje važno.

I u izometričkoj, kao i u relaksacijskoj skupini nakon tretmana dolazi do statistički značajnog smanjenja boli i povećanja gibljivosti vrata, pri čemu je djelovanje učinka tretmana na promatrane kriterije veliko. Nakon provedene terapije bol je smanjena na umjerenu, a gibljivost vrata znatno poboljšana. U izometričkoj skupini djelovanje statičkih vježbi i vježbi disanja kod osoba s nespecifičnom boli u vratu može se objasniti promjenama tlaka unutar mišića i aktivacijom tetivnih receptora u skladu s hipotezom Cinderella. ${ }^{12}$ Izometrička kontrakcija aktivira sva mišićna vlakna i povećava tlak u mišiću, što onemogućava dotok krvi u cijeli mišić. Nakon kontrakcije osoba ima za cilj maksimalno relaksirati aktivne mišiće, a samim time smanjiti tlak unutar mišića i omogućiti dotok krvi. Ako postoji nerazmjer tlakova unutar mišića, oni bi se trebali normalizirati te omogućiti uspostavu homeostatskog stanja u preopterećenim mišićnim vlaknima. Izometrička kontrakcija aktivira Golgijev tetivni aparat u svim aktivnim mišićima i stvara proprioceptivne informacije koje mogu inhibirati informacije iz nociceptora u stražnjem rogu kralježnične moždine i smanjiti osjećaj boli. ${ }^{11}$

U relaksacijskoj skupini djelovanje manipulativne tehnike na paravertebralne mišiće i mišiće ramenog obruča te djelovanje trakcije i mobilizacije vrata kod osoba s nespecifičnom boli u vratu može se objasniti promjenama tlaka unutar mišića i aktivacijom tetivnih i mišićnih receptora. I ovdje hipoteza Cinderella može objasniti dobivene nalaze jer primijenjena terapija djeluje na uravnoteženje tlaka unutar mišića zbog načina regrutacije motornih jedinica, ${ }^{12}$ što za posljedicu ima poboljšanje cirkulacije i uspostavu homeostaze. Mobilizacija vrata u mogućem opsegu pokreta dovodi do aktivacije mišićnih vretena, Golgijevih tetivnih aparata i receptora u ligamentima te proprioceptivne informacije, po već navedenom principu smanjuju osjećaj boli. ${ }^{11}$

Za obje vrste tretmana pokazalo se da nejednako djeluju na gibljivost vrata u različitim ravninama kod iste osobe, odnosno najveće djelovanje ne pojavljuje se u istoj ravnini kod različitih sudionika.

Glede djelovanja terapijskih postupaka na ravnotežne reakcije (test ravnoteže na klupici i test „ustani i kreni”), došlo je do znatnog poboljšanja, a efekt tretmana je velik. Opisano znatno smanjenje boli i poboljšanje pokretljivosti vrata omogućilo je bolje balansiranje glave, te bolje prikupljanje proprioceptivnih informacija iz mišića, tetiva i ligamenata vrata, bolje informacije iz vestibularnog aparata, manji pritisak na arteriju vertebralis, korištenje vratom za fokusiranje, što se sve pozitivno odražava na ravnotežne reakcije sudionika. Sudionici imaju manji strah i nesigurnost zbog mogućnosti provjere okoline i lakšeg planiranja aktivnosti. Sigurniji su i stabilniji kad moraju reagirati u aktivnostima i s ponavljanjem su sve bolji. Samim time vid nije toliko potreban za održavanje ravnoteže, nema potrebe za stalnim fokusiranjem nekog predmeta i osoba nije u strahu prilikom brže promjene pogleda. U penjanju ili silasku s klupice primjećuje se da sudionici imaju uspravnije držanje i ne hvataju se rukama za okolinu. Kad razgovaraju, pogled im je usmjeren k sugovorniku i usude se promijeniti položaj trupa i nogu da bi promijenili mjesto stajanja.

lako je došlo do poboljšanja u ravnoteži, možemo reći da rezultati testa ravnoteže na klupici nisu zadovoljavajući, jer nakon terapije na obje noge dulje od trideset sekundi može stajati $67 \%$ sudionika, a samo $23 \%$ dulje od šezdeset sekundi. Razlog može ležati u prisutnosti kronične boli kod $67 \%$ pacijenata, jer kronična bol 
mijenja motorički slijed izvođenja aktivnosti u vratu. Terapijski su postupci omogućili smanjenje boli i bolju pokretljivost, ali za vraćanje aktivnosti duboke skupine mišića vrata, poboljšanje koordinacije duboke i površinske skupine mišića vrata bit će potreban duži period uz vježbe koordinacije.

Usporedba djelotvornosti promatranih terapijskih metoda kod dviju skupina pacijenata $s$ nespecifičnom boli u vratu pokazuje statistički značajnu razliku za frontalni indeks: izometrička skupina postiže znatniji napredak. No razlika u napretku iznosi samo $1 \mathrm{~mm}$ te nema bitno kliničko značenje. Značajna razlika dobivena je i za test ravnoteže za desnu nogu, također u korist izometričke skupine. Za sve druge kriterijske varijable nije utvrđena statistički značajna razlika među grupama, kao ni njihova interakcija. Izometrička skupina u većoj je mjeri napredovala i u testu ravnoteže za lijevu nogu, ali ta razlika od gotovo 6 sekundi nije značajna, što dobrim dijelom možemo pripisati velikom varijabilitetu rezultata unutar skupina. Adekvatno objašnjenje za dobivanje značajne razlike među skupinama samo za desnu nogu nije nam poznato.

Možemo zaključiti da su oba terapijska pristupa djelotvorna u smanjivanju nespecifične boli u vratu, ali njihov učinak nije drastično različit. Djelovanje statičkih vježbi i vježbi disanja primijenjenih u izometričkoj skupini čini se da ima donekle jače djelovanje na pojedine kriterije. Objašnjenje za utvrđene razlike možemo naći u aktivnom pristupu tretmanu koji se zahtijeva od pacijenata u izometričkoj skupini. Oni ulažu vlastiti napor u poboljšanje stanja svojih mišića te usklađuju njihov rad s ritmom disanja. Kontrola disanja uvjetuje bolju izmjenu plinova i pospješuje tjelesno i psihičko opuštanje pacijenta. Nadalje, nakon svladavanja vježbi, pacijenti su educirani kako da si sami pomognu kod ponavljanja simptoma pa je s tog aspekta ovaj tretman isplativiji nego tretman u relaksacijskoj skupini koji uvijek zahtijeva asistenciju kompetentne osobe. Za razliku od izometričke, pacijenti u relaksacijskoj skupini imaju u većoj mjeri pasivnu ulogu, jer se terapija „provodi na njima”.

Situaciju donekle zamućuje prisutnost višestrukih tretmana koji ugrožavaju unutrašnju valjanost $u$ istraživanju te na koncu nemamo jasnu informaciju o učinku isključivo tretmana od interesa. lako su obje grupe imale propisane identične dodatne tretmane, precizna evidencija o redoslijedu njihova odvijanja, kao ni ritmu dolazaka na terapije nije vođena, što predstavlja propust u ovom istraživanju.

Unatoč složenom pristupu, u objema skupinama nalazimo sudionike na koje je terapija minimalno djelova- la, a razlozi mogu biti u pogrešnom dijagnosticiranju problema, nepridržavanju uputa odnosno nedostatku odmora od rada ili nedovoljnom broju tretmana. $\mathrm{Na}$ to ukazuju nalazi nekih istraživanja da se nespecifična bol u vratu mora liječiti pet mjeseci do godinu dana. ${ }^{1,13}$

Naše istraživanje ima određenih ograničenja. Osim već navedenih višestrukih tretmana, na prvom je mjestu malen uzorak sudionika koji nije po slučaju podijeljen po skupinama. Također, u situaciji nemogućnosti slučajne raspodjele potrebno je kontrolirati i druge važne čimbenike, npr. zanimanje pacijenata i konzumaciju lijekova. Svakako treba više pažnje posvetiti boljoj kontroli aktivnosti u slobodno vrijeme, kao i evidenciji redoslijeda terapijskih aktivnosti. Osim toga, od velike važnosti bilo bi promatrati i dugoročne, a ne samo kratkoročne učinke terapije, npr. nakon tri ili šest mjeseci.

\section{Zaključci}

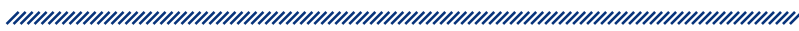

Kod dvije skupine pacijenata s nespecifičnom boli u vratu primjenjivale su se dvije različite terapijske metode: manipulacija mekog tkiva, trakcija i mobilizacija glave (relaksacijska skupina) odnosno statičke vježbe snage i vježbe disanja u svrhu relaksacije (izometrična skupina). Mjerenje boli, indeksa pokretljivosti i ravnoteže u obje skupine prije terapije pokazuje prisutnost jake boli, ograničene pokretljivosti u vratu i kratkotrajno održavanje ravnoteže na jednoj nozi, pri čemu ne postoji značajna razlika među skupinama. Analiza varijance za ponovljena mjerenja pokazala je da obje metode znatno pozitivno djeluju na sve promatrane varijable, pri čemu se veličine njihovih učinaka kreću od velikih do izrazito velikih. Došlo je do znatnog smanjenja boli i povećanja gibljivosti u kratkom periodu, što se pozitivno odrazilo i na ravnotežne reakcije. Napredak grupa međusobno se značajno razlikuje samo u frontalnoj gibljivosti i testu ravnoteže na klupici za desnu nogu. Izometrička skupina postiže statistički značajno veći napredak u frontalnoj gibljivosti, iako je navedena razlika vrlo mala. Izometrička je skupina znatno bolja i u testu ravnoteže na desnoj nozi.

Obje terapijske metode ublažile su tegobe i poboljšale stanje pacijenata s nespecifičnom boli u vratu, a postoje sporadični pokazatelji o većoj djelotvornosti statičkih vježbi snage i vježbi disanja. 


\section{Literatura}

1. Bruflat AK, Balter JE, McGuire D, Fethke NB, Maluf KS. Stress management as an adjunct to physical therapy for chronic neck pain. J Am Phys Ther Assoc. 2012; 92(10): 1348-1359.

2. Andersen $\mathrm{CH}$, Andersen LL, Mortensen OS, Zebis MK, Sjøgaard G. Protocol for Shoulder function training reducing musculoskeletal pain in shoulder and neck: a randomized controlled trial. BMC Musculoskelet Disord. 2011; 12(1): 14.

3. Zebis MK, Andersen LL, Pedersen P. Implementation of neck/shoulder exercises for pain relief among industrial workers: a randomized controlled trial. BMC Musculoskelet Disord. 2011; 21(12): 205.

4. Bjorklund M, Djupsjobacka M, Svedmark A. Effects of tailored neck-shoulder pain treatment based on a decision model guided by clinical assessments and standardized functional tests. A study protocol of a randomized controlled trial. BMC Musculoskelet Disord. 2012; 20(13): 75.

5. Haldeman S, Dagenais S. Cervicogenic headaches: a critical review. Spine J. 2001; 1(1): 31-46.

6. Jorgensen MB, Skotte JH, Holterman A. Neck pain and postural balance among workers with high postural demands - a cross-sectional study. BMC Musculoskelet Disord. $2011 ; 1$ (12): 176.

7. Aaras A, Horgen G. The effect of an ergonomic Intervention on musculoskeletal, psyhosocial and visual strain of VDT data entry work: the Norwegian part of the international study. Int J Occup Saf Ergon. 2005; 11(1): 25-47.

8. Radulović B, Huršidić-Radulović A. Frequency of musculoskeletal and eye symptoms among computer users at work. Arh Hig Rada Toksikol. 2012; 1(63;2): 215-218.

9. Judaš M, Kostović I. Temelji neuroznanosti. Zagreb: MD; 1997.

10. Roijezon U, Bjorklund M, Bergenheim M. A novel method for neck coordination exercise - a pilot study on persons with chronic non-specific neck pain. J Neuroeng Rehabil. 2008; 23(5): 36.

11. McPartland JM, Brodeur RR. Chronic neck pain, standing balance, and suboccipital muscle atrophy-a pilot study. J Manipulative Physiol Ther. 1997; 20(1): 24-29.

12. Hägg GM. Static work loads and occupational myalgia - a new explanation model. U: Anderson PA, Hobart DJ, Danoff JV, ur. Electromyographical Kinesiology. Amsterdam: Elsevier Science Publishers; 1991: 141-144.

13. Kadi F, Hägg G, Håkansson R, Holmner S, Butler-Brown GS, Thornell LE. Structural changes in male trapezius muscle with work-related myalgia. Acta Neurolpathol (Berl). 1998; 95: 352-360. Citirano u: Andersen CH. Effect of different training regimes on musculoskeletal pain in neck and shoulder. National Research Center for the Working Environment. 2012.
14. Quek JM, Pua YH, Bryant AL, Clark RA. The influence of cervical spine flexion-rotation range-of-motion asymmetry on postural stability in older adults. Spine. 2013; 38(19): 1648-1655.

15. Keros P, Pećina M. Funkcijska anatomija lokomotornog sustava. Medicinska biblioteka. Zagreb: Naklada Ljevak; 2006.

16. Nordin M, Frankel VH. Basic biomechanics of the musculoskeletal system. New York: Lippincott Williams and Wilkins; 2001.

17. Donald AN. Kinesiology of the musculoskeletal system. Milwaukee: Mosby Elsevier; 2010.

18. Ylininen J, Takala EP, Nykanen M. Active neck muscle training in the treatment of chronic neck pain in women. JAMA. 2003; 21(289;19): 2509-2516.

19. Andersen $\mathrm{CH}$, Andersen LL, Gram B. Influence of frequency and duration of strength training for effective management of neck and shoulder pain: a randomised controlled trial. Br J Sports Med. 2012; 46(14): 1004-1010.

20. Aker PD, Gross AR, Goldsmith CH. Conservative management of mechanical neck pain: systematic overview and meta-analysis. BMJ. 1996; 23(313;7068): 1291-1296.

21. Bronford G, Haas M. Efficacy of spinal manipulation and mobilization for low back pain and neck pain: a systematic review and best evidence synthesis. Spine J. 2004; 4(3): 335-356.

22. Andersen $\mathrm{CH}$. Effect of different training regimes on musculoskeletal pain in neck and shoulder. National Research Center for the Working Environment: 2012. Dostupno na: www.arbejdsmiljoforskning.dk/da/nyheder/arkiv/2012/ / media/Boeger-og-rapporter/cha-phd.pdf (pristupljeno 20. listopada 2013.).

23. Sran MM. To treat or not to treat: new evidence for the effectivnes of manual therapy. Br J Sports Med. 2004; 38: 521-525.

24. Hoving JL, Koes BW. Manual therapy, physical therapy, or continued care by a general practitionar for patients with neck pain. A randomized, controlled trial. Ann Intern Med. 2002; 21(136;10): 713-722.

25. Borman P, Keskin D. The efficacy of intermittent cervical traction in patents with chronic neck pain. Clinical Rheumatology. 2008; 27: 1249-1253.

26. Asama Y, Goto F, Tsutsumi T. Objective evaluation of neck muscle tension and static balance in patients with chronic dizziness. Acta otolaryngologica. 2012; 132(11): 1168-1171.

27. Kammermeier S, Kleine JF, Eggert T. Disturbed vestibular-neck interaction in cerebellar disease. Journal of neurology. 2013; 260(3): 794-804.

28. Hubbard B, Pothier D, Hughes C. A portable, low-cost system for posturography: a platform for longitudinal balance telemetry. Journal of otolaryngology. 2012; Suppl. 1: 31-35.

29. Harald M, Papke K, Oberwittler C. Scales And Scores In Neurology. Stuttgart: Thieme Medical Publishere; 2003.

30. Kolesarić V, Tomašić Humer J. Veličina učinka. Osijek: Filozofski fakultet Sveučilišta Josipa Jurja Strossmayera; 2016. 


\section{A COMPARISON OF TWO PHYSIOTHERAPY TREATMENT APPROACHES FOR NONSPECIFIC NECK PAIN}

1 Tomislav Rumbak

2 Olivera Petrak

1 Special Hospital for Medical Rehabilitation Krapinske Toplice

2 Department of Health Psychology, University of Applied Health Sciences, Zagreb

\section{Abstract

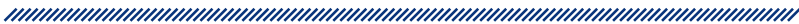

Neck pain is one of the most common pain sensation caused by long-term head restraint in one position, long-lasting stereotypic activity, reduced physical activity and stress. Pain is associated with restricted rang of neck motion and postural balance difficulties, especially in chronic state. There are numerous methods of treating nonspecific neck pain, but evidence of their effectiveness is still lacking.

The aim of this study was to determine efficacy of two different physiotherapy approaches to pain reduction, increasing sagittal, frontal and transverse mobility index and balance improvement in patients with nonspecific neck pain.

Research was conducted in Special Hospital for Medical Rehabilitation Krapinske Toplice, and 30 patients were included. Half of them were treated by physiotherapist through the methods of soft tissue manipulation, traction and neck mobilisation (relax group). The other group of fifteen participants was educated for perform- ing static strength exercises and breathing exercises for relaxation (isometric group). Observed variables were range of motion, pain and balance measured before and after 15 -day therapy. Sample included $80 \%$ of women and $20 \%$ of men, with an average age of 55.6 years in isometric group, and 52.4 years in relax group. There is no significant difference between two groups in age, gender, or others criteria of interest.

Prior to therapy there is severe pain, range of neck motion is limited, and one legged maintaining balance last shortly, where there is no significant difference between the groups. The results after the therapy show positive changes, with very large effect size: both methods have a significant effect on pain reduction, improvement in neck mobility in all observed planes, and on results in "One-leg balance" test and „Timed Up and Go" test. There is no significant interaction between the groups for any of the observed criteria.

There were significant difference between two groups in frontal flexibility, and in right leg balance: isometric group achieved significantly bigger improvement. Both therapeutic methods were effective for decreasing neck difficulties and improving the condition of patients with nonspecific neck pain, and there are sporadic indicators that static strength and breathing exercises are more effective.

Keywords: nonspecific neck pain, range of neck motion, manipulation and mobilisation for neck pain, isometric neck exercises. 